\title{
Fossil sea lilies of the genus Isselicrinus Rovereto, 1914 from the lower Oligocene, Eastern Rhodopes (Bulgaria)
}

\author{
Lidiya Kirilova ${ }^{1}$, Vladimir Georgiev² \\ ${ }^{1}$ Regional Museum of History Kardzhali, 4 Republikanska Str., 6600 Kardzhali, Bulgaria; e-mail: lidiak@gbg.bg \\ ${ }^{2}$ Geological Institute, Bulgarian Academy of Sciences, Acad. G. Bonchev Str., Bl. 24, 1113 Sofia, Bulgaria; \\ e-mail:vlado69geo@abv.bg
}

(Accepted in revised form: March 2018)

\begin{abstract}
Fossil sea lilies of the genus Isselicrinus Rovereto, 1914 were found near the village of Raven, Momchilgrad Municipality, in the Eastern Rhodopes in 1978. They were recovered from the rocks of the Raven complex. The latter is composed of rhyolite pyroclastics with layers of reef limestones. With the $\mathrm{Ar} / \mathrm{Ar}$ method, the pyroclastics of the Raven complex have been dated as 31.19-30.97 Ma (early Oligocene). The presence of reef limestones suggests shallow coastal waters with normal salinity and a warm climate, in which Isselicrinus lived. These were the outskirts of a tropical basin, inhabited by faunas, which today have their descendants in the tropical areas.
\end{abstract}

Kirilova, L., Georgiev, V. 2018. Fossil sea lilies of the genus Isselicrinus Rovereto, 1914 from the lower Oligocene, Eastern Rhodopes (Bulgaria). Geologica Balcanica 47 (1), 37-41.

Keywords: Isselicrinus sp., family Isselicrinidae, taxonomy, lower Oligocene, Eastern Rhodopes, Bulgaria.

\section{INTRODUCTION}

Crinoids are marine animals that belong to the class Crinoidea, phylum Echinodermata. The name of the class comes from the Greek words krinon, "a lily", and eidos, "form" (see Craig, 1847, p. 438). They first appeared during the Ordovician and have survived until now (Hess et al., 1999).

The body of each mature crinoid consists of three parts: column (stem), cup (calyx), and arms. The cup and the arms form the so-called crown. The stem is attached to the substrate with root-like structures of different shapes. It is built of cylindrical, circular, elliptical or pentagonal columnals - nodals and internodals. Nodals bear lateral segmented tentacles called cirri, the internodals being located between them.

The connective articular surface of the columnals is sculpted in different ways, depending on the type of articulation. The columnals with pentagonal shape hold five leaf-shaped pits on the connective surface, which are named petals. Articulation is accomplished by fine ribs and grooves - crenulae, movably con- nected by ligaments in the pits (Hess and Messing, 2011).

Compared to their Mesozoic counterparts, fossil records of Palaeogene and Miocene crinoids are quite poor. This is not due to the lack of species diversity during the early Neozoic, but because of poor preservation of fossil specimens. Therefore, finding wellpreserved specimens of that age is a great rarity (Hess et al., 1999; Hess and Messing, 2011). Still, there are many registered fossil crinoids from the lower Palaeocene, which include species of the genera Cainocrinus, Calamocrinus, Isselicrinus, Nielsenicrinus, and Bourgueticrinus (Hess et al., 1999).

Among fossil Palaeogene crinoids, with the exception of two or three species, which are preserved with cups, all others are identified based on fragments of stems or arms, or both (Moore and Vokes, 1953). The discovered complete specimens are very few in number, e.g., Isselicrinus subbasaltiformis (Miller, 1821) from the early Eocene of Denmark and England, and Raymondicrinus oregonensis (Moore and Vokes, 1953) from the early Oligocene 
of north-western Oregon (Hess et al., 199; Hess and Messing, 2011).

\section{MATERIAL AND LOCALITIES}

The material used for this study comprises fossilized parts of crinoid stems from the fund of the Regional Museum of History in Kardzhali, registered under the inventory number Kn 150 and discovered in 1978 in the vicinity of the village of Raven, Momchilgrad Municipality (4132'49.86"N, 25²9'32.65"E, altitude $472 \mathrm{~m}$ a.s.l.; Fig. 1). The fragments are six pieces with the following dimensions: lengths $12 \mathrm{~mm}, 17 \mathrm{~mm}$, $22 \mathrm{~mm}, 26 \mathrm{~mm}, 35 \mathrm{~mm}$, and $37 \mathrm{~mm}$; diameter in crosssection $10 \mathrm{~mm}$ for all fragments.

\section{DATING AND GEOLOGICAL SETTING}

The region of study is situated in the eastern part of the Morava-Rhodope Zone (Dabovski et al., 2002). During the period between the Late Cretaceous and the Eocene, the Rhodope Massif was affected by processes of extension (Ivanov, 2000). As a result, metamorphic core complexes (domes) were formed, among which depressions emerged. In the Eastern Rhodopes, several depressions with a specific area of volcanism were formed. They have been combined into the East Rhodope Palaeogene depression (Ivanov, 1960) and the East Rhodope complex depression (Georgiev, 2012). During the Eocene and the Oligocene, this depression represented a shallow basin, and it was a setting of intense sedimentation and abundant volcanism.

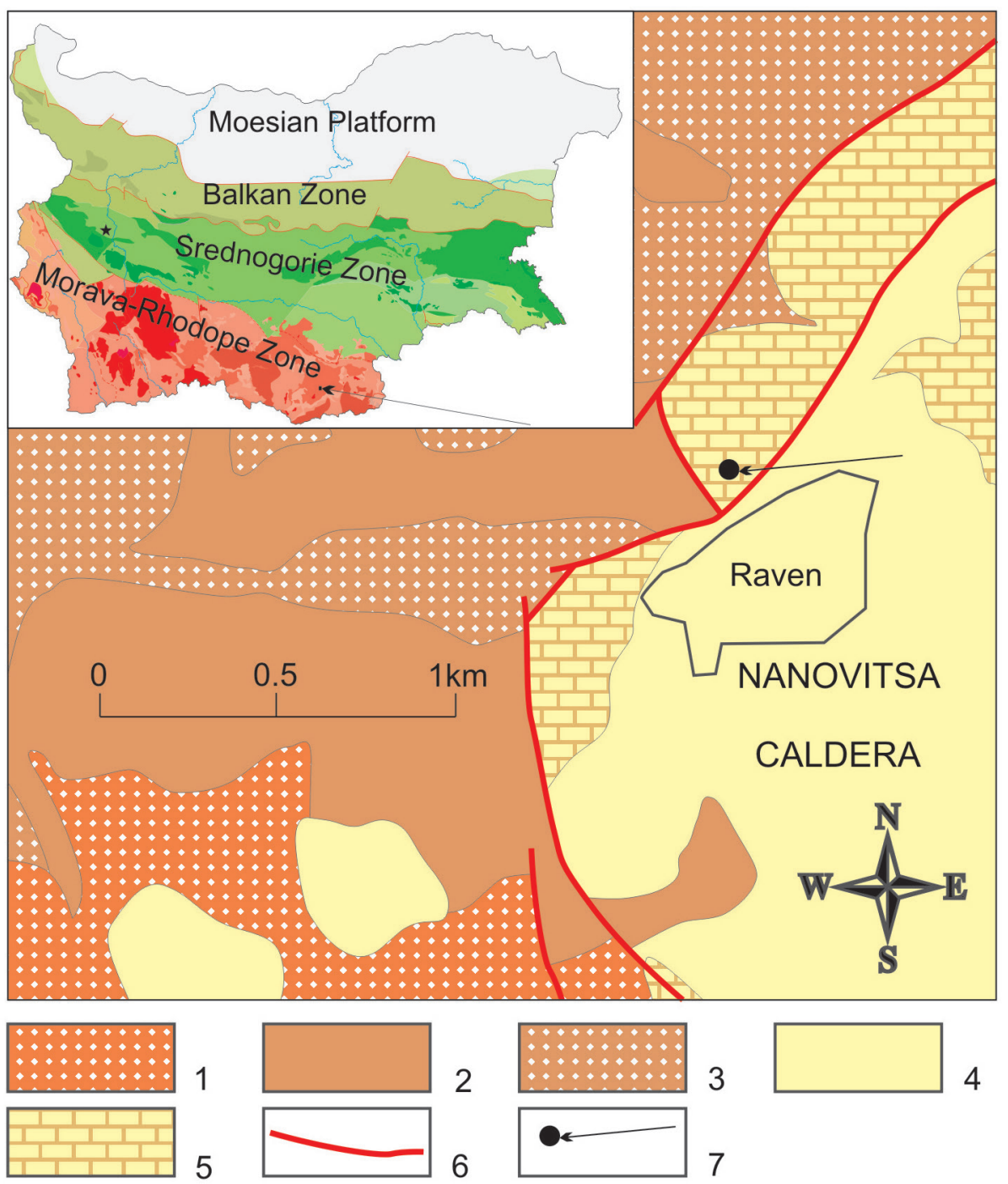

Fig. 1. Geological map of the area (tectonic scheme after Dabovski et al., 2002): 1 - Zvezdel andesite-basalt complex, pyroclastite; 2, 3 - Momchilgrad trachydacite complex, lava flow (2), pyroclastite (3); 4, 5 - Raven rhyolite complex, pyroclastite (4), limestone (5); 6 - fault; 7 - fossil locality. 
Sedimentary rocks are exposed mainly in the lower parts of the section, whereas the higher parts consist mainly of volcanic rocks with acidic and intermediate composition. The area concerned herein is a part of the Momchilgrad depression. Within it, the Dambala magmatic group was formed, which consists (from bottom to top) of the Kalabak andesite, the Rabovo latite-andesite, the Zvezdel basaltic-andesite, the Sveti Iliya trachyrhyodacite, the Momchilgrad trachydacite, and the Raven rhyolite complexes. They are all intersected by dykes of the Pcheloyad complex, represented by rhyolites and latites. It is assumed that the products of this complex originated from one magma chamber (Georgiev, 2012). The general trend in the evolution of magmatism of the group is from intermediate to acidic composition (Georgiev, 2012).

The studied fossils were found in rocks from the Raven complex. It is built of rhyolite pyroclastics with layers of reef limestones. Among them are embedded sub-volcanic rhyolite bodies of the same complex. The materials of the Raven complex fill up the Nanovitsa caldera, which is located in the inner parts of the Momchilgrad depression. The reef limestones, in which the studied fossils were found, are positioned in the western part of the caldera, just north of the village of Raven (Fig. 1). Based on Ar/Ar dating, the age of the pyroclastics of the Raven complex has been estimated as 31.19-30.97 Ma (Georgiev and Marchev, 2005).

\section{SYSTEMATIC PALAEONTOLOGY}

The classification of Hess and Messing (2011) is adopted herein.

Phylum Echinodermata Bruguière, 1791 [ex Klein, 1734]

Class Crinoidea Miller, 1921

Subclass Articulata Zittel, 1879

Order Isocrinida Sieverts-Doreck in: Moore et al., 1952

Suborder Isocrinina Sieverts-Doreck in: Moore et al., 1952

Family Isselicrinidae Klikushin, 1977

Subfamily Isselicrininae Klikushin, 1977

\section{Genus Isselicrinus Rovereto, 1914 (emend. Ras- mussen, 1954)}

Type species. Isselicrinus insculptus Rovereto, 1914, by monotypy.

Remarks. The first isselicrinids were described on the basis of segmented stalks of Pentacrinus didactylus d'Orbigny in: d'Archiac, 1846 (see Klikushin, 1977a; Hess and Messing, 2011, pp. 61-63) found in the Eocene at Biaritz, France (didactylus comes from "two cirri", which means two-fingered). Subsequently, Rovereto (1914) introduced a new genus, Isselicrinus, for these isocrinids with smooth stems and 2-3 cirrus sockets on the nodals (Klikushin, 1977a).

\section{Isselicrinus sp. (Fig. 2)}

Description. Among the six fragments of stems, only one bears a nodal at the distal (lower) end and fifteen preserved internodals connected to it. The stems have a pentagonal profile when viewed in cross-section. The latera is smooth. The articular facet of the columnals shows distinct marginal crenulae. The crenulae become longer radially and outline the external borders of each areola. The petals are broad, with teardrop to rhombic shape. Clearly visible is a double adradial ridge separated by a groove not reaching the periphery of the lumen. The nodal has two cirrus sockets located on its lower edge (Fig. 2). The observed traits allows the material to be assigned to the genus Isselicrinus Rovereto, 1914 (Klikushin, 1977a; Hess and Messing, 2011).

Discussion. The articulate crinoids Isselicrinus are an extinct genus of the family Isselicrinidae, which lived from the latest Cretaceous to the Miocene (Klikushin, 1982) and had a wide geographical distribution. The genus is characterized by one to three cirri on the lower edge of the nodal, unlike other isocrinids where cirri reach up to five per nodal. The peripheral crenulae are distinctly marked; adradial ridges are present on the articular surface of the columnals. The cross-section of the stem changes from star-shaped in the proximal part to a nearly circular-shaped in the distal part. In the middle part of the stem, the columnals are pentagonal (Moore and Jeffords, 1968; Klikushin, 1977b; Oji, 1990; Jagt, 1999; Hunter, 2012). Typical for the genus is the long internode (series of non-cirrus-bearing internodals between successive nodals) and, therefore, the cirri on the stem are located distantly from one another. This strange morphology suggests a mode of life different from that of the other Isocrinina, which employ their numerous, long cirri for anchoring to the substrate. In many cases, Isselicrinus are found in muddy sediments, unlike modern isocrinines, which occupy high-energy environments of coarse sand or gravel. In connection to this, Isselicrinus are regarded as crinoids adapted to low-energy muddy environments. Under these conditions, they cannot find solid particles, such as small pebbles, rock substrate, etc., and they, therefore, do not have long cirri. As a result, they have adopted another way of attachment, characteristic for the genus, called "relay strategy", where each individual is attached to the pre-existing upright stem, thus forming a bundle, which is used for anchoring to the bottom (Fujiwara et al., 2005).

Isselicrininae in Bulgaria. According to Klikushin (1977a, 1992), the specimens of Pentacrinus cingulatus (Schafh, 1863) identified by Gochev (1933) in the Eocene deposits of Aladanska Quarry near Varna (NE Bulgaria) are actually equivalent to Isselicrinus subbasaltiformis (Miler, 1821), Pentacrinus subbasaltiformis var. subrotundus (Gregorio, 1894), and Pentacrinites sowerbyi (Wetherell, 1837). This, however, has not been confirmed by later publications 

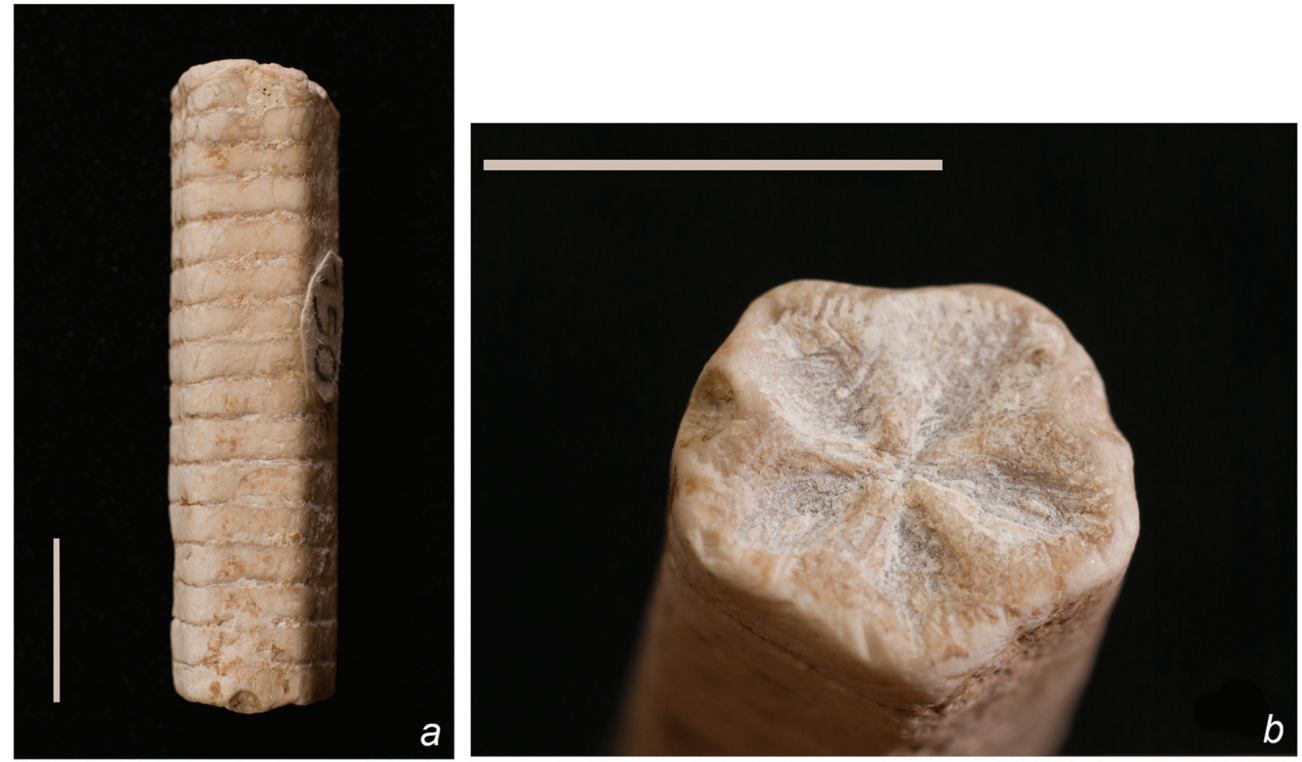

Fig. 2. Isselicrinus sp., lower Oligocene, village of Raven, Eastern Rhodopes, Bulgaria: $a$ ) column; $b$ ) distal facet of nodal with two cirrus sockets. Scale bar $=1 \mathrm{~cm}$.

concerning the distribution of the genus (see Hess and Messing, 2011).

Stratigraphical distribution. Numerous species from the Eocene and rarely from the Oligocene and Miocene are included in this genus (Rasmussen, 1972; Oji, 1990). From the Cretaceous (Maastrichtian) to the Palaeogene, species of the genus show relatively wide distribution, especially in Europe. During the Neogene, Isselicrinus declined and gradually went extinct, probably during the Miocene (Oji, 1990).

Geographical distribution. Different species of this genus have been registered in Armenia, Austria, Denmark, England, France, Germany, Hungary, Italy, Spain, Sweden, Switzerland, the former territories of Yugoslavia, in the Caucasus, Crimea, Iran, Tunisia, Algeria, Borneo, Japan, Greenland, the USA (New Jersey), South America (Tierra del Fuego), Cuba, and Haiti (see Klikushin, 1982; Hess and Messing, 2011; Astibia et al., 2016).

\section{CONCLUSION}

This is the first report in Bulgaria marking the presence of the genus Isselicrinus in this part of Europe during the early Oligocene. As seen above, the fossil crinoids of this period are a worldwide rarity. The discovery of representatives of the genus Isselicrinus in the early Oligocene deposits of the Eastern Rhodopes is an important fact, which concerns the biogeography and ecology of the genus during this period. The fossil Isselicrinus specimens are found in rhyolite pyroclastics with layers of reef limestones. The presence of reef limestones suggests shallow coastal waters with normal salinity and a warm climate. These were the outskirts of a tropical basin, inhabited by faunas, which today have their descendants in the tropical areas. The corals and mostly stenohaline molluscs are an indication of normal seawater salinity (32-35\%) (see Sapoundžieva and Yanev, 1984; Boyanov and Goranov, 2001; Kirilova and Georgiev, 2015).

\section{Acknowledgements}

The authors are indebted to Dr Tomasz Baumiller (University of Michigan, USA) and Prof. Iskra Lakova (Geological Institute, Bulgarian Academy of Sciences) for useful critical readings of the manuscript.

\section{REFERENCES}

Astibia, H., Payros, A., Ortiz, S., Elorza, J., Álvarez-Pérez, G., Badiola, A., Bardet, N., Berreteaga, A., Calzada, S., Carmelo Corral, J., Díaz-Martínez, I., Merle, D., Pacaud, J.-M., Pereda-Suberbiola, X., Pisera, A., Rodríguez-Tovar, F.J.,
Tosquella, J., Bitner. M.A. 2016. Fossil associations from the middle and upper Eocene strata of the Pamplona Basin and surrounding areas (Navarre, western Pyrenees). Iberian journal of Geology 42 (1), 7-28. 
Boyanov, I., Goranov, A. 2001. Late Alpine (Palaeogene) superimposed depressions in parts of Southeast Bulgaria. Geologica Balcanica 31 (3-4), 3-36 (in English, with Russian abstract).

Craig, J. A. 1874. New Universal Etymological and Pronouncing Dictionary of the English language, embracing all the terms used in art, science and literature. Volume 1, London, $1054 \mathrm{pp}$.

Dabovski, C., Boyanov, I., Chrischev, Ch., Nikolov, T., Sapunov, I., Yanev, Y., Zagorchev, I. 2002. Structure and Alpine evolution of Bulgaria. Geologica Balcanica 32 (2-4), 9-15.

Fujiwara, S.-I., Oji, T., Tanaka, Y., Kondo, Y. 2005. Relay strategy and adaptation to a muddy environment in Isselicrinus (Isselicrinidae: Crinoidea). Palaios 20, 241-248.

Georgiev, S., Marchev, P. 2005. Oligocene pyroclastic rocks and a petrified forest in the Nanovitsa depression. Geochemistry, Mineralogy and Petrology 42, 47-65.

Georgiev, V. 2012. Metallogeny of the Eastern Rhodopes. Prof. Marin Drinov Publishing House, Sofia, 162 pp. (in Bulgarian, with English abstract).

Gochev, P. 1933. Palaeontologic and stratigraphic studies on the Eocene in the region of Varna. Review of the Bulgarian Geological Society 5 (1), 1-65 (in Bulgarian).

Hess, H., Ausich, W.I., Brett, C.E., Simms, M.J. (Eds). 1999. Fossil crinoids. Cambridge University Press, Cambridge, $299 \mathrm{pp}$.

Hess, H., Messing, Ch. 2011. Treatise on Invertebrate Paleontology, Part T, Echinodermata 2, Revised, Crinoidea Volume 3. The University of Kansas Paleontological Institute, Lawrence, Kansas, 261 pp.

Hunter, A.W. 2012. Crinoid diversity in the Upper Cretaceous Yezo Supergroup, Hokkaido, northern Japan. Zoosymposia 7, 71-79.

Ivanov, R. 1960. Der magmatismus in der paläogene senkung der ostrodopen. 1. Teil. Geologie. Travaux sur la géologie de Bulgarie, Série de géochimie et des gites métallifères et non-métallifères 1, 312-338 (in Bulgarian, with German abstract).

Ivanov, Z. 2000. Tectonic position, structure and tectonic evolution of Rhodope massif. In: Guide to excursion $A B C D-$ GEODE 2000 Workshop, Borovets, Bulgaria, 1-6.
Jagt, J.W.M. 1999. Late Cretaceous-Early Palaeogene echinoderms and the K/T boundary in the southeast Netherlands and northeast Belgium - Part 2: Crinoids. Scripta Geologica 116B, 59-255.

Kirilova, L., Georgiev, V. 2015. Rhodopotilapia gracialis new fossil genus and species of family Cichlidae. Early Oligocene, Eastern Rhodopes, Bulgaria. Comptes rendus de l'Académie bulgare des Sciences 68 (11), 1413-1418.

Klikushin, V.G. 1977a. Sea lilies of the genus Isselicrinus. Paleontologicheskiy Zhurnal 1, 87-95 (in Russian).

Klikushin, V.G. 1977b. Paleogene isocrinids of Crimea. Paleontologicheskiy Zhurnal 3, 109-117 (in Russian).

Klikushin, V.G. 1982. Taxonomic survey of fossil isocrinids with a list of the species found in the USSR. Géobios 15 (3), 299-325.

Klikushin, V.G. 1992. Fossil pentacrinid crinoids and their occurrence in the USSR. Leningrad Palaeontological Laboratory, Sankt-Peterburg, 358 pp. (in Russian, with English abstract).

Moore, R.C., Jeffords, R.M. 1968. Classification and nomenclature of fossil crinoids based on studies of dissociated parts of their columns. University of Kansas Paleontological Contributions, Serial No. 46, Echinodermata, 48-49.

Moore, R.C., Vokes, H.E. 1953. Lower Tertiary crinoids from northwestern Oregon. United States Geological Survey Professional Paper 233-E, 113-148.

Oji, T. 1990. Miocene Isocrinidae (stalked crinoids) from Japan and their biogeographic implication. Transactions and Proceedings of the Palaeontological Society of Japan, New Series 157, 412-429.

Rasmussen, H.W. 1972. Lower Tertiary Crinoidea, Asteroides and Ophiuroidea from Northern Europe and Greenland. Biologiske Skrifter det Kgl. Danske Videnskaberus Salskab 19, 1-83.

Rovereto, G. 1914. Nuovi studi sulla stratigrafia e sulla fauna dell'Oligocene ligure. Olivieri E. \& C., Società Tipo-Litografica Ligure, Genova, $179 \mathrm{pp}$.

Sapoundžieva, V., Yanev, Y. 1984. Fauna from the sandstones near Džebel, East Rhodopes. Review of the Bulgarian Geological Society 45 (3), 308-317 (in Bulgarian, with English abstract). 